Nadwa | Jurnal Pendidikan Islam

Vol. 9, Nomor 1, April 2015

\title{
Rekrutmen Tenaga Pendidik dalam Peningkatan Mutu Madrasah Aliyah Negeri Insan Cendekia Jambi
}

\author{
K.A. Rahman, Ardiansyah, dan Marwazi \\ Institut Agama Islam Negeri Sulthan Thaha Saifuddin Jambi \\ Email: kemas.rahman@gmail.com
}

\begin{abstract}
Abstrak
Tujuan penelitian ini adalah untuk mengetahui proses rekrutmen tenaga pendidik dalam peningkatan mutu Madrasah Aliyah Negeri Insan Cendikia Jambi. Metode yang digunakan deskiptif kualitatif. Teknik pengumpulan data menggunakan observasi, wawancara dan studi dokumen. Hasil penelitian menunjukan bahwa proses rekrutmen guru yang dilakukan sudah baik. Kegiatan rekrutmen ini diawali dengan perencanaan kebutuhan guru, pengumuman adanya lowongan guru, persyaratan yang harus dipenuhi calon guru, seleksi dengan berbagai tes, dan penentuan penerimaan guru. Peneliti menyarankan agar kegiatan rekrutmen tenaga pendidik pada MAN Insan Cendekia Jambi di pertahankan, bila perlu ditingkatkan agar lebih baik lagi. Terutama dalam pengumuman lowongan guru diperpanjang dan berkas-berkas yang berkaitan dengan rekrutmen guru sebaiknya diarsipkan.
\end{abstract}

Kata kunci: Rekrutmen, Tenaga Pendidik, Mutu Madrasah

\begin{abstract}
The purpose of this research is to know the process of teacher recruitment to improve the quality of Madrasah Aliyah Negeri Insan Cendikia Jambi. The method used descriptively qualitative. Data collection used observation, interview, and document study. The result of the research showed that the process of teacher recruitment whice conducted was good. The recruitment activity was began by planning of teacher need that was by analyzing the present teacher need, the announcement of teacher vacancy, the requirement that should be acquired by teacher candidate, using some test in selection section, and deciding teacher acceptance. Researchers suggested the teacher recruitment activity at MAN Insan Cendikia Jambi should be kept, or improved if possible. Especially in the vacancy announcement extended teacher and files relating to the recruitment of teachers should be archived.
\end{abstract}

Keyword: Recruitment, Teachers, Madrasah Quality 


\section{Pendahuluan}

Peningkatan mutu pendidikan sangat berkaitan erat dengan masalah SDM, oleh karena itu proses rekrutmen SDM merupakan hal yang sangat penting sekali dan hanya akan dapat diperoleh melalui upaya rekrutmen yang efektif. Oleh karena itu beberapa aspek guru professional yang harus menjadi perhatian adalah mekanisme penerimaan, pembinaan profesional, pengembangan karir dan tingkat kesejahteraan guru. ${ }^{1}$

Rekrutmen adalah proses mencari, menemukan dan menarik pelamar yang kapabel untuk dipekerjakan dalam dan oleh organisasi. ${ }^{2}$ Mekanisme penerimaan guru hendaknya mendapat perhatian yang utama. Karena pada tahap penerimaan ini dapat memilih dan menyeleksi calon-calon guru sesuai dengan kriteria yang diinginkan bagi cita-cita dan tujuan pendidikan yang akan dicapai. Kesalahan dalam menyeleksi guru dapat berakibat fatal bagi kelangsungan kegiatan pembelajaran dalam hubungannya dengan pencapaian tujuan dan cita-cita lulusan yang diinginkan. ${ }^{3}$

Proses rekrutmen tenaga pendidik dalam lembaga pendidikan di sekolah adalah berusaha mencari guru yang memiliki kompetensi, kecakapan dan ahli dalam mendidik dan mengajar sesuai bidangnya di samping itu yang sangat penting dimiliki oleh seorang guru adalah sifat jujur serta memiliki jasmani yang sehat sehingga dapat menjalankan tugasnya dalam mencerdaskan anak bangsa. Berdasarkan firman Allah SWT dalam surah Al-Qoshos ayat 26 sebagai berikut:

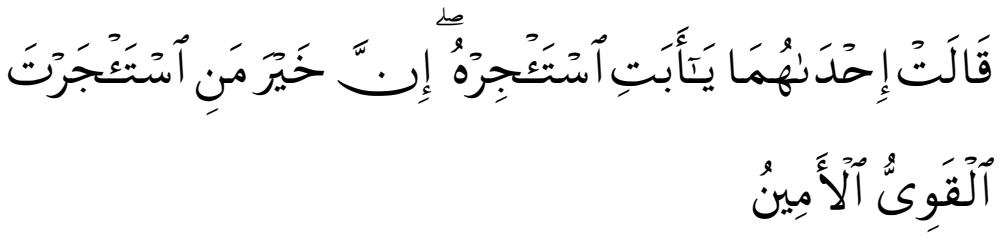

"Salah seorang dari kedua wanita itu berkata: "Ya bapakku ambillah ia sebagai orang yang bekerja (pada kita), karena Sesungguhnya

\footnotetext{
${ }^{1}$ Supiana, Sistem Pendidikan Madrasah Unggulan di Madrasah Aliah Negeri Insan Cendekia Tangerang, Madrasah Aliyah Negeri I Bandung dan Madrasah Aliyah Negeri Darussalam Ciamis, (Badan Litbang Dan Diklat Depag RI, 2008), hal. 292

${ }^{2}$ Sondang P. Siagian, Manajemen Sumber Daya Manusia, (Jakarta: Bumi Aksara, 2009), hal. 102

${ }^{3}$ Supiana, Sistem Pendidikan ... .hal. 292
} 
orang yang paling baik yang kamu ambil untuk bekerja (pada kita) ialah orang yang kuat lagi dapat dipercaya"."4

Mekanisme penerimaan tenaga pendidik hendaknya mendapat perhatian yang utama dalam hal proses perekrutannya. Karena pada tahap ini, pemilik wewenang dapat memilih dan menyeleksi caloncalon guru sesuai kriteria yang diinginkan bagi cita-cita dan tujuan pendidikan yang akan dicapai. Apabila terjadi kesalahan pada tahap perekrutan dan penyeleksian tenaga pendidik dapat berakibat fatal bagi kelangsungan kegiatan pembelajaran yang berdampak pada pencapaian tujuan dan cita-cita suatu lembaga pendidikan tersebut. Sebab sekolah yang berhasil adalah sekolah yang dapat mencetak peserta didik berkualitas dan berprestasi. Berdasarkan hadist Rasulullah SAW yang diriwayatkan oleh Bukhari sebagai berikut:

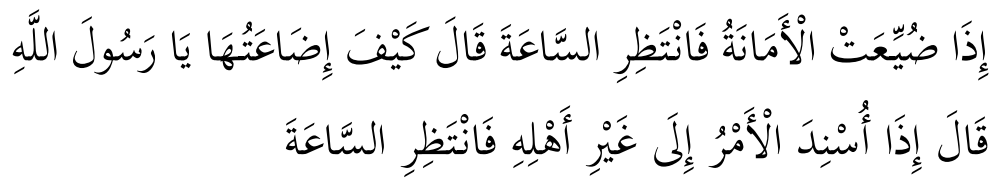

"Rasulullah shallallahu 'alaihi wasallam bersabda: "Jika amanat telah disia-siakan, tunggu saja kehancuran terjadi." Ada seorang sahabat bertanya; 'bagaimana maksud amanat disia-siakan? ' Nabi menjawab; "Jika urusan diserahkan bukan kepada ahlinya, maka tunggulah kehancuran itu." (BUKHARI - 6015). ${ }^{5}$

Pendidikan bermutu adalah pendidikan yang mampu melakukan proses pematangan kualitas peserta didik yang dikembangkan dengan cara membebaskan peserta didik dari ketidaktahuan, ketidakmampuan, ketidakberdayaan, ketidakbenaran, ketidakjujuran, dan dari buruknya akhlak dan keimanan. Pendidikan bermutu lahir dari sistem perencanaan yang baik (good planning system) dengan materi dan sistem tata kelola yang baik (good governance system) dan disampaikan oleh guru yang baik (good teachers) dengan komponen pendidikan yang bermutu, khususnya guru. ${ }^{6}$

Berdasarkan studi pendahuluan (grand tour), didapati bahwa proses rekrutmen tenaga pendidik pada MAN Insan Cendekia

${ }^{4}$ Anonim, Al-Qur'an dan Terjemahnya, hal. 613

${ }^{5}$ Imam Bukhori, Shohih Bukhori, Juz I, (Bairut; Daar Al Kutub, 2008), hal. 37

${ }^{6}$ Dedi Mulyasana, Pendidikan Bermutu dan Berdaya Saing, (Bandung: PT. Remaja Rosdakarya, 2012), hal. 120 
Jambi dilakukan melalui kerjasama dengan MAN Insan Cendekia Serpong, sehingga diharapkan memperoleh tenaga pendidik yang kompeten pada Madrasah Aliyah Negeri (MAN) Insan Cendekia Jambi. Tenaga pendidik yang profesional inilah nantinya diharapkan mampu meningkatkan mutu sekolah dalam hal prestasi peserta didik dilihat dari mutu prestasi, mutu lulusan, dan mutu sebaran lulusan.

Tenaga pendidik MAN Insan Cendekia Jambi merupakan tenaga pendidik pilihan. Di antara tenaga pendidik di MAN Insan Cendekia ini ada yang menjadi guru teladan se-Provinsi Jambi. Ada juga yang menjadi narasumber dalam pelatihan Kurikulum 2013 seProvinsi Jambi. Ada pula yang menjadi dewan juri OSN (olimpiade) SMK tahun 2009.

Adapun mutu lulusan siswa MAN Insan Cendekia Jambi pada tahun pelajaran 2013/2014 program studi IPA dengan jumlah nilai tertinggi 54,20 dengan rata-rata 9,70 sementara nilai terendah 42,90 dengan rata-rata 5,60, dan nilai rata-rata keseluruhan siswa MAN Insan Cendekia program IPA 48,83. Sedangkan pada program studi IPS jumlah nilai tertinggi 51,10 dengan rata-rata 9,40, jumlah nilai terendah 39,20 dengan rata-rata 5,20 dan nilai rata-rata keseluruhan siswa MAN Insan Cendekia pada program IPS adalah 48,34. ${ }^{7}$

Berdasarkan deskripsi latar belakang masalah di atas, maka rumusan masalah dalam penelitian ini adalah:

1. Bagaimana mutu madrasah pada MAN Insan Cendekia Jambi?

2. Bagaimana proses rekrutmen tenaga pendidik pada MAN Insan Cendekia Jambi?

3. Mengapa rekrutmen tenaga pendidik yang efektif dapat meningkatan mutu madrasah pada MAN Insan Cendekia Jambi?

Berdasarkan rumusan masalah di atas, maka tujuan dan kegunaan penelitian ini adalah:

1. Untuk mengetahui mutu madrasah pada MAN Insan Cendekia Jambi

2. Mendeskripsikan dan menjelaskan proses pelaksanaan rekrutmen tenaga pendidik dalam peningkatan mutu madrasah di MAN Insan Cendekia Jambi.

${ }^{7}$ Dokumentasi, Hasil UN MAN Insan Cendekia Jambi Tahun Pelajaran $2013 / 2014$ 
3. Untuk mengetahui sejauhmana rekrutmen tenaga pendidik yang efektif dapat meningkatan mutu MAN Insan Cendekia Jambi.

\section{Pengertian Rekrutmen}

Menurut Irwin, The role of human resource recruitment is to build a supply of potential new hires that the organization can draw on if the need arises. Recruiting consists of any practice or activity carried on by the organization with the primary purpose of identifying and attracting potential emloyees. ${ }^{8}$ Peran perekrutan sumber daya manusia adalah untuk membangun pasokan potensial karyawan baru bahwa organisasi dapat menariknya jika diperlukan. Merekrut terdiri dari praktik atau kegiatan yang dijalankan oleh organisasi dengan tujuan utama mengidentifikasi dan menarik karyawan potensial.

Sedangkan menurut Dubois yang dikutip oleh Suwatno dan Donni Juni Priansa menyatakan bahwa: "Recruitment is the process of attracting as many qualified applicant as possible for existing vacancies and anti cipated openings. It is a talent of the best group of applicants for an available position." Rekrutmen merupakan proses menarik sebanyak mungkin kualifikasi pelamar untuk lowongan yang ada dan bukan di antisipasi. Ini merupakan pencarian bakat, pengejaran kelompok terbaik pelamar untuk posisi tersedia. ${ }^{9}$

Menurut E. Mulyasa, rekrutmen yaitu suatu upaya untuk mencari dan mendapatkan calon-calon tenaga kependidikan yang memenuhi syarat sebanyak mungkin untuk kemudian dipilih calon terbaik dan tercakap. Untuk kepentingan tersebut perlu dilakukan seleksi, melalui ujian lisan, tulisan dan perbuatan/ praktek. ${ }^{10}$ Rekrutmen merupakan usaha yang dilakukan untuk memperoleh sumber daya manusia yang dibutuhkan untuk mengisi jabatan-jabatan tertentu yang masih kosong. Selain itu, rekrutmen merupakan usahausaha mengatur komposisi sumber daya manusia secara seimbang sesuai tuntutan melalui proses penyeleksian.

\footnotetext{
${ }^{8}$ Irwin, Fundamentals Of Human Resource Management, (New York: McGraw-Hill, 2011), hal. 136

${ }^{9}$ Suwatno dan Doni Juni Priansa, Manajemen SDM dalam Organisasi Publik dan Bisnis (Bandung: Alfabeta, 2013), hal. 63

${ }^{10}$ E. Mulyasa, Menjadi Kepala Sekolah Profesional (Bandung: Remaja Rosdakarya, 2007), hal.153
} 


\section{Proses Rekrutmen}

Proses rekrutmen dimulai dengan mempertimbangkan rencanarencana SDM seperti mempertimbangkan jumlah dan tipe dari posisi kosong yang harus diisi, kapan posisi tersebut harus diisi, sumber personil atau keahlian apa yang dibutuhkan untuk mengisi posisi tersebut. Setelah dilakukan pertimbangan tersebut maka dilanjutkan penentuan strategi dan metode rekrutmen. Terdapat berbagai metode rekrutmen dalam mendapatkan calon tenaga kerja. Sumber calon tenaga kerja bisa berasal dari internal atau eksternal organisasi. ${ }^{11}$

Berdasarkan teori yang telah dikemukakan, maka yang dimaksud dengan rekrutmen dalam penelitian ini adalah proses pencarian dan pemilihan sejumlah calon tenaga pendidik (guru) untuk dapat mengajar sesuai dengan bidang keilmuan yang dimiliki masing-masing dari pelamar sehingga dapat mentransfer ilmu yang dimilikinya kepada peserta didik pada MAN Insan Cendekia Jambi. Adapun indikator dari rekrutmen tenaga pendidik pada penelitian ini di antaranya adalah 1) pemilihan berdasarkan kebutuhan lembaga, 2) kredibilitas dari calon tenaga pendidik, 3) Perekrutan tenaga pendidik pada yang menjadi prioritas adalah pengalaman kerja, 4) kesempatan yang sama untuk setiap calon tenaga pendidik (guru) untuk bergabung pada lembaga pendidikan MAN Cendekia ini.

\section{Tenaga Pendidik}

Dari segi bahasa, seperti yang dikutip Abudin Nata dari WJS, Poerwadarminta pengertian pendidik adalah orang yang mendidik. Pengertian ini memberikan kesan, bahwa pendidik adalah orang yang melakukan kegiatan dalam bidang mendidik. Pendidik dalam bahasa Inggris disebut teacher yang artinya guru atau pengajar, ${ }^{12}$ dalam bahasa Arab disebut Ustadz, Mudarris, Mu'adib dan Mu'alim yang artinya yang mengajar, guru. Dalam literatur lainnya dikenal guru, dosen, pengajar, tutor, lecturer, educator, atau trainer.

11 Wukir, Manajemen Sumber Daya Manusia Dalam Organisasi Sekolah, (Yogyakarta: Multi Presindo, 2013), hal.59.

12 Jhon M. Echols dan Hassan Shadily, Kamus Inggris Indonesia, (Jakarta:Gramedia Pustaka Utama, 2003), hal 581 
Peran guru yang penting dalam mendorong pembelajaran siswa adalah meningkatkan keinginan siswa atau motivasi untuk belajar. ${ }^{13}$ Sebagai para pendidik, guru seharusnya melakukan hal-hal sebagai berikut: a) Menyediakan beragam contoh dan representasi materi pelajaran pada para pembelajar, b) Mendorong tingkat interaksi yang tinggi dalam pengajaran, c) Menghubungkan materi pelajaran dengan dunia nyata. ${ }^{14}$

\section{Mutu Madrasah}

Pada era kontemporer dunia pendidikan model pengelolaannya berbasis industri. Pengelolaan model ini mengandaikan adanya upaya pihak pengelola institusi pendidikan untuk meningkatkan mutu pendidikan berdasarkan manajemen perusahaan. Penerapan manajemen mutu dalam pendidikan ini lebih populer dengan sebutan istilah Total Quality Education (TQE), dasar dari manajemen ini di kembangkan dari konsep Total Quality Management (TQM), yang pada mulanya diterapkan pada dunia bisnis kemudian diterapkan pada dunia pendidikan. ${ }^{15}$

Dalam konteks pendidikan, pengertian mutu mengacu pada masukan, proses, luaran, dan dampaknya. Mutu masukan dapat dilihat dari beberapa sisi. Pertama, kondisi baik atau tidaknya masukan sumber daya manusia, seperti kepala sekolah, guru, laboran, staf tata usaha, dan siswa. Kedua, memenuhi atau tidaknya kriteria masukan meterial berupa alat peraga, buku-buku, kurikulum, prasarana, sarana sekolah, dan lain-lain. Ketiga, memenuhi atau tidaknya kriteria masukan yang berupa perangkat lunak, seperti peraturan, struktur organisasi, deskripsi kerja, dan struktur organisasi. Keempat, masukan yang bersifat harapan dan kebutuhan, seperti visi, motivasi, ketekunan, dan cita-cita. ${ }^{16}$

Berdasarkan teori yang telah dikemukakan, maka yang dimaksud dengan mutu madrasah pada penelitian ini adalah madrasah yang memiliki dan melahirkan peserta didik yang berkualitas

${ }^{13}$ David A. Jacobsen, Paul Eggen, Donald Kauchak, Metode-metode Pengajaran Meningkatkan Belajar Siswa TK-SMA, (Yogyakarta: Pustaka Pelajar, 2009), hal. 11

${ }^{14}$ David A. Jacobsen, ... hal. 10

${ }^{15}$ Edward Sallis, Total Quality Management In Education, (Jogjakarta: IRCiSoD, 2006), hal. 5

${ }^{16}$ Sudarwan Danim, Visi Baru Manajemen Sekolah dari Birokrasi ke Lembaga Akademik, (Jakarta: Bumi Aksara, 2006), hal. 53 
dengan segudang prestasi baik prestasi yang sifatnya di dalam (intern) madrasah maupun di luar (ekstern) madrasah, sehingga madrasah ini dikenal dengan sebutan madrasah yang bermutu dan berkualitas. Adapun indikator pencapaian mutu madrasah yang paling menonjol saat ini adalah (1) Mutu input pembelajaran, (2) Mutu proses pembelajaran, dan (3) Mutu output pembelajaran. ${ }^{17}$

\section{Metode Penelitian}

\section{Pendekatan Penelitian}

Penelitian ini tergolong dalam penelitian deskriptif kualitatif yaitu suatu studi yang berusaha mengungkapkan, mencari, menemukan serta menggali informasi dan fakta dengan interpretasi yang tepat tentang rekrutmen tenaga pendidik dalam peningkatan mutu sekolah pada MAN Insan Cendekia Jambi. Penelitian ini menggunakan pendekatan deskriptif kualitatif yang menggambarkan gejalagejala, fakta-fakta atau kejadian yang terjadi pada objek penelitian secara apa adanya.

Dalam operasionalnya, peneliti observasi langsung ke lapangan yaitu di MAN Insan Cendekia Jambi untuk mendengarkan, mengamati, bertanya, dan mencatat kemudian difahami berdasarkan interpretasi peneliti, kemudian dibandingkan dengan hasil penelitian sebelumnya, dengan menggunakan referensi untuk dijadikan dasar dan penguat data yang ditemukan di lapangan.

\section{Situasi Sosial dan Subjek Penelitian}

Situasi sosial adalah lokasi atau tempat yang ditetapkan untuk melakukan penelitian. Karena penelitiannya adalah riset sosial atau lingkungan manusia atau budaya maka dinamakan dengan situsi sosial (social Setting). ${ }^{18}$ Adapun lokasi sosial (social setting) yang dipilih pada penelitian ini adalah MAN Insan Cendekia Jambi, adapun sebagai bahan pertimbangan memilih madrasah ini menjadi setting penelitian ini karena merupakan sekolah yang bermutu dalam prestasi siswa dan termasuk sekolah favorit jika dibandingkan dengan madrasah lain yang ada di provinsi jambi.

${ }^{17}$ Euis Karwati dan Donni Juni Priansa, Kinerja dan profesionalisme kepala sekolah Membangun Sekolah yang bermutu, (Bandung: Alfabeta, 2013) hal 54

${ }^{18}$ Mukhtar, Metode praktis Penelitian Deskriptif Kualitatif, (Jakarta: Referensi (GP Press group, 2013), hal. 88 


\section{Subjek Penelitian}

Adapun yang menjadi subjek pada penelitian ini adalah segala aspek yang terkait dengan rekrutmen tenaga pendidik pada MAN Insan Cendekia Jambi, meliputi : Kepala Madrasah, Kepala TU, tenaga pendidik (Guru), serta elemen yang terkait dalam proses rekrutmen. Dalam penetapannya menggunakan purposive sampling yaitu teknik pengambilan sampel sumber data dengan pertimbangan tertentu. Misalnya orang tersebut yang dianggap paling tahu apa yang kita harapkan, atau mungkin dia sebagai penguasa sehingga memudahkan peneliti menjelajahi obyek/situasi sosial yang diteliti. 19

\section{Jenis dan Sumber Data}

Data merupakan jenis-jenis sumber yang diperoleh peneliti pada subjek penelitiannya, data yang diperlukan dalam penelitian ini adalah data yang dapat dimaknai untuk diinterpretasikan dalam rangka menggambarkan lebih rinci tentang rekrutmen tenaga pendidik dalam peningkatan mutu sekolah di MAN Insan Cendekia Jambi. Data tersebut bisa saja dalam bentuk argumen yang direkam untuk dapat dijabarkan lebih lanjut, demikian juga temuan-temuan selama pengamatan, dan juga dokumen yang diperoleh dari sumber yang valid.

Pada penelitian ini penulis memperoleh data melalui observasi langsung dengan melihat dokumen-dokumen tertulis serta arsiparsip pada MAN Insan Cendekia Jambi. Adapun data tersebut antara lain Profil Madrasah yang menyangkut di dalamnya: histori dan geografis MAN Insan Cendekia Jambi, struktur madrasah, sarana dan prasarana, keadaan tenaga pendidik dan kependidikan, serta berbagai prestasi sekolah yang telah diraih.

\section{Teknik Pengumpulan dan Analisis Data}

Dalam penelitian kualitatif terdapat tiga teknik pengumpulan data, yaitu observasi, wawancara, dokumentasi. Dalam penelitian ini, teknik pengumpulan data primer menggunakan metode wawancara tidak terstruktur, yang dilakukan dengan cara membuat pedoman wawancara yang hanya memuat garis besar pertanyaan yang akan diajukan kepada orang-orang yang berkompeten dalam kegiatan pengelolaan manajemen di MAN Insan Cendekia Jambi,

${ }^{19}$ Sugiyono, Metode penelitian Kuantitatif Kualitatif, dan R\&D, (Bandung: Alfabeta, 2013) Hal 218 
antara lain; Kepala Madrasah, Kepala TU, guru, staf, konsultan pendidikan.

Analisis data pada penelitian ini mencakup : reduksi data, kategorisasi data, sintesisasi, dan diakhiri dengan menyusun hipotesis kerja. $^{20}$

6. Uji Keterpercayaan Data (Pemeriksaan Keabsahan Data)

Dalam penelitian kualitatif untuk mendapatkan data yang validitas dan realibilitas harus melalui prosesi pengujian keabsahan data terlebih dahulu yang diperoleh melalui proses observasi, wawancara dan dokumentasi. Uji kredibilitas data dilakukan dengan cara perpanjangan pengamatan, peningkatan ketekunan pengamatan, triangulasi, pengecekan teman sejawat, pengecekan anggota, analisis kasus negatif, kecukupan referensial. ${ }^{21}$

\section{Deskripsi Lokasi, Temuan Penelitian dan Analisis Hasil Penelitian}

Sejarah awal berdirinya MAN Insan Cendekia Jambi yaitu di prakarsai oleh Kakanwil Departemen Agama Provinsi Jambi yang saat itu dijabat oleh Drs. H.M. Idris Saleh (Alm) dan kepala bidang Mapenda dipimpin oleh Drs. H. Arfah Hap, MM, selanjutnya di komunikasikan dengan Bupati Muaro Jambi saat itu yang dijabat oleh Drs. H. As'ad Syam, sehubungan rencana penempatan madrasah ini berada dikawasan Kabupaten Muaro Jambi yang tidak jauh dari Kota Jambi.

Awal pembangunan MAN Insan Cendekia Jambi berlangsung pada tahun 2003 di atas tanah 5 hektar atas pemberian hak pakai tanah pemerintah Kabupaten Muaro Jambi, sedangkan penetapan akta pendiriannya bukan tahun 2003, tapi penetapan pendiriannya dilakukan tanggal 4 Desember 2004 oleh Departemen Agama RI.

Madrasah Aliyah Negeri (MAN) Insan Cendekia Jambi adalah suatu madrasah yang terletak di Jalan lintas Jambi - Muara Bulian KM 21 Kecamatan Jambi Luar Kota Kabupaten Muaro Jambi Provinsi Jambi, tepatnya berada di sebelah kanan jalan. MAN Insan Cendekia Jambi berdiri di areal 5 hektar. ${ }^{22}$

${ }^{20}$ Lexy J. Moleong, Metodologi penelitian Kualitatif Edisi Revisi, (Bandung: PT. Remaja Rosdakarya, 2005), Hal. 288

21 Nusa Putra dan Santi Lisnawati, Penelitian Kualitatif Pendidikan Agama Islam, Jakarta: Remaja Rosdakarya, 2012, hal. 33-34

${ }^{22}$ Nusa Putra dan Santi Lisnawati, Penelitian ... 


\section{Mutu MAN Insan Cendekia Jambi}

Mutu merupakan produk yang sempurna, bernilai dan meningkatkan kewibawaan. Mutu dalam konteks pendidikan sangat penting, karena berkaitan dengan lembaga yang terdiri dari komponen peserta didik, pendidik, tenaga kependidikan dan proses penyelenggaraan pendidikan. Agar mutu pendidikan yang baik dapat tercapai, maka mutu tersebut harus didukung oleh sekolah yang bermutu. Sekolah yang bermutu adalah sekolah yang secara keseluruhan dapat memberikan kepuasan kepada pelanggan.

Dalam penelitian ini yang dimaksud mutu adalah lebih menekankan pada produk dari manajemen madrasah itu sendiri yaitu peserta didik yang memiliki berbagai prestasi baik di tingkat lokal, regional maupun di tingkat nasional, memilki lulusan yang bermutu dan berdaya saing sehingga dapat diterima di perguruan tinggi ternama.

Dilihat dari data prestasi peserta didik MAN Insan Cendekia Jambi yang ditemukan dapat ditarik kesimpulan bahwa mutu prestasi peserta didik MAN Insan Cendekia Jambi sudah sangat baik, hal ini dapat dilihat dari perolehan mendali yang tiap tahun diraih oleh peserta didik MAN Insan Cendikia Jambi, mulai dari tingkat lokal, regional, hingga prestasi di tingkat Nasional.

Mutu lulusan (output) adalah kualitas peserta didik dilihat dari perolehan nilai akhir yang sangat ditentukan dari proses belajar mengajar, jika proses belajar mengajar baik dan efektif maka mutu lulusan (output) akan baik dan sebaliknya jika proses belajar mengajar tidak efektif maka akan berpengaruh terhadap mutu lulusan (output).

Berdasarkan hasil wawancara dengan $\mathrm{MH}$ selaku kepala madrasah bahwa : MAN Insan Cendekia Jambi selalu berupaya untuk selalu memperbaiki proses belajar mengajar pada peserta didik baik pada jam efektif di dalam kelas maupun diluar jam efektif agar mutu lulusan (output) peserta didik di madrasah ini semakin meningkat ke arah yang lebih baik. ${ }^{23}$ pernyataan sesuai dengan teori yang dikemukakan pakar, bahwa output dapat dilihat dari aktivitas sekolah yaitu seberapa banyak yang dipelajari dan seberapa baik mempelajarinya.

\section{Sekolah}

${ }^{23}$ Kepala Madrasah, Mashuri, wawancara, 07 Maret 2015, Pijoan, Mutu 
MAN Insan Cendekia Jambi setiap tahunnya meluluskan siswa dan siswinya dengan nilai rata-rata yang diraih dalam ujian nasional (UN) berpredikat baik. Ini merupakan salah satu bukti berhasilnya proses kegiatan belajar mengajar yang dilaksanakan di MAN Insan Cendekia Jambi dan ini juga menandakan bermutunya suatu sekolah.

Dari hasil temuan di atas dapat penulis simpulkan bahwa mutu lulusan MAN Insan Cendekia Jambi sudah baik, hal ini dapat dilihat dari hasil ujian nasional dari tahun 2009/2010 hingga 2013/2014. Siswa memperoleh nilai ujian nasional tertinggi ada yang mencapai rata-rata 9,90 pada tahun pelajaran 2012/2013.

Mutu sebaran lulusan (outcome) adalah kualitas peserta didik yang dapat melanjutkan pendidikan ke jenjang yang lebih tinggi dan jika tidak melanjutkan pendidikan, maka dalam dunia kerja dapat diterima dengan baik, mandiri, serta diterima dengan baik dalam kehidupan bermasyarakat.

Berdasarkan hasil wawancara dengan kepala Madrasah bapak MH bahwa salah seorang peserta didik di MAN Insan Cedekia Jambi pada tahun 2015 ini ada yang diterima (lulus) di IRKUTS University Rusia atas nama Frisca Intan Luzia. Alhamdulillah ini merupakan bukti bahwa lulusan madrasah kami memiliki kualitas dan mampu bersaing dengan sekolah lain sehingga membanggakan dan meningkatkan grade lembaga ini. ${ }^{24}$

2. Proses Rekrutmen Tenaga Pendidik di MAN Insan Cendekia Jambi

Berdasarkan hasil wawancara di atas pelaksanaan rekrutmen tenaga pendidik pada MAN Insan Cendikia Jambi bahwa sebelum pelaksanaan rekrutmen dilakukan, perlu adanya perencanaan yang mengaitkannya dengan identifikasi lowongan dan informasi tentang analisis pekerjaan.

Dari hasil wawancara dengan Bapak Mashuri terlihat bahwa MAN Insan Cendekia Jambi memang sangat selektif dalam memilih guru yang berkualitas guna menunjang pendidikan yang bermutu. Ketika guru terbaik yang mengajar dengan segenap keahliannya maka akan mencetak generasi penerus bangsa yang berkualitas di bidang sains dan Agama.

Adapun sumber rekrutmen yang digunakan oleh madrasah ini dijelaskan oleh bapak Muhsin, bahwa "sumber dalam perekrutan

${ }^{24}$ Kepala Madrasah, Mashuri, wawancara ... 
tenaga pendidik yang dimanfaatkan oleh Madrasah ini dalam mendapatkan guru baru yang kompeten,profesional yaitu lebih kepada sumber eksternal. Rekrutmen disini terbuka untuk umum, terbuka disini berarti bisa diikuti oleh semua orang yang berkompeten baik PNS maupun non PNS, proses rekrutmen antara guru PNS dan non PNS yang mengajukan menjadi guru di MAN Insan Cendekia ini sama tetap diadakan seleksi sesuai standar madrasah ini, upaya ini dilakukan tidak lain adalah agar memperoleh guru yang mampu mendidik dan mengajar siswa disini menjadi siswa berkualitas yang memiliki keilmuan dibidang agama dan sain". 25

Dijelaskan juga oleh ibu ZK sebagai wakil kepala madrasah bidang humas yang sebelumnya wakil bidang kurikulum, "sumber informasi yang dimanfaatkan oleh sekolah adalah internal dan eksternal. Alasan menggunakan sumber internal yaitu dapat dipertanggungjawabkan oleh guru atau pegawai yang orang yang merekomendasikan. Kalau sumber eksternal alasannya adalah agar memperoleh calon tenaga pendidik yang memiliki kompetensi, dedikasi, loyalitas yang tinggi terhadap kemajuan lembaga" ${ }^{26} \mathrm{Pi}-$ hak sekolah memanfaatkan berbagai sumber baik internal maupun eksternal untuk mencapai tujuannya. Tidak masalah sumber yang diperoleh dari mana yang terpenting adalah pelamar tersebut sesuai dengan kualifikasi yang di butuhkan sekolah. Sehingga baik sumber dari dalam atau dari luar harus mengikuti tes yang diselenggarakan oleh tim rekrutmen dan sekolah tidak menerima guru mutasi untuk mengajar.

Berdasarkan hasil wawancara peneliti dengan MS Tim rekrutmen tenaga pendidik pada MAN Insan Cendekia Jambi terbagi menjadi dua yaitu 1) tim rekrutmen dari dalam yaitu berasal dari MAN Insan Cendekia Jambi merupakan tim rekrutmen pemberkasan, jadi berkas pelamar calon guru diserahkan kepada tim rekrutmen yang berasal dari dalam, 2) tim rekrutmen dari Serpong merupakan tim seleksi, tujuan tim rekrutmen di datangkan dari serpong oleh pihak Kementerian Agama RI adalah untuk memperoleh

${ }^{25}$ Kepala Madrasah, Mashuri, wawancara ...

${ }^{26}$ WAKA Humas MAN IC Jambi, Zakiyah, Wawancara, 7 Maret 2015, Pijoan, proses rekrutmen, Muaro Jambi. 
tenaga pendidik yang betul-betul kompeten dibidangnya dan untuk menghindarkan proses seleksi yang tidak bersih. ${ }^{27}$

3. Rekrutmen Tenaga Pendidik yang Efektif dalam Peningkatan Mutu MAN Insan Cendekia

Menurut keterangan yang diberikan oleh MS selaku kepala madrasah periode pertama MAN Insan Cendekia Jambi bahwa: "Kontribusi rekrutmen tenaga pendidik di MAN Insan Cendekia Jambi ini sangat menentukan mutu lembaga, karena jika tenaga pendidik berkualitas dalam mengajar sesuai dengan kualifikasi pendidikannya, serta memiliki loyalitas dengan lembaga insya Allah akan menghasilkan peserta didik yang berkualitas dan tentunya akan meningkatkan mutu sekolah". ${ }^{28}$

Hal senada juga disampaikan oleh MH selaku kepala madrasah mengatakan bahwa: "agar memiliki guru yang berkualitas sangat tergantung pada kualitas proses rekrutmennya. Semakin baik prosesnya, semakin besar pula kemungkinan didapatkannya individuindividu yang sangat memenuhi kualifikasi sesuai dengan yang diharapkan oleh sekolah. Rekrutmen tenaga pendidik bertujuan mengumpulkan calon guru sebanyak mungkin sesuai dengan kualifikasi yang dibutuhkan sekolah untuk dipilih dari yang terbaik diantara yang baik. Pelaksanaan rekrutmen merupakan tugas yang sangat penting dan krusial, karena kualitas tenaga pendidik dalam suatu sekolah sangat ditentukan dari proses rekrutmen dan seleksi yang dilakukan lembaga tersebut. Apabila rekrutmen dilakukan dengan baik maka akan diperoleh tenaga pendidik yang berkualitas sementara jika proses rekrutmen tidak baik maka sekolah tidak akan memperoleh tenaga pendidik yang berkualitas". ${ }^{29}$

\section{Kesimpulan}

Berdasarkan hasil penelitian yang dilakukan tentang sudi Rekrutmen Tenaga Pendidik dalam Peningkatan Mutu Sekolah Pada MAN Insan Cendekia Jambi, dapat diambil kesimpulan sebagai berikut:

27 TU MAN IC Jambi, Muhsin, Wawancara, 20 Desember 2014, Pijoan, proses rekrutmen, Muaro Jambi..

${ }^{28}$ Kepala Madrasah Tahun pertama Sept 2006 s.d Juni 2014, Muslim, Wawancara, 24 Juni 2015, Kanwil Kemanag Provinsi Jambi, Kota Jambi.

${ }^{29}$ Kepala Madrasah Tahun 2014/2015, Mashuri, Wawancara, 06 Juni 2015, Pijoan, proses rekrutmen, Muaro Jambi. 
1. Mutu Madrasah Aliyah Negeri Insan Cendekia Jambi dapat dilihat dari mutu lulusan, mutu sebaran lulusan dan mutu prestasi siswa. Mutu lulusan dilihat dari hasil ujian nasional peserta didik di MAN Insan Cendekia memperoleh nilai tertinggi dengan rata-rata 9,70 untuk program IPA, sedangkan nilai tertinggi program studi IPS dengan rata-rata 9,40. Mutu sebaran lulusan, peserta didik di MAN Insan Cendekia Jambi banyak yang diterima di perguruan tinggi favorit di Indonesia seperti UI, UGM, ITB dan perguruan tinggi lainnya. Selanjutnya dari mutu prestasi siswa, peserta didik di MAN Insan Cendekia banyak meraih juara pada perlombaan baik ditingkat regional maupun ditingkat Nasional.

2. Proses rekrutmen tenaga pendidik sebagai upaya untuk mendapatkan guru yang potensial dan memiliki kompetensi dibidangnya sesuai dengan kulifikasi MAN Insan Cendekia Jambi. Pelaksanaan rekrutmen tenaga pendidik ini terbagi menjadi dua kepanitian, yaitu panitia internal (dalam) dan panitia eksternal (luar), panitia internal terdiri dari TU yang mengumpulkan berkas dan persyaratan calon guru, sedangkan panitia eksternal yaitu tim penguji yang khusus di datangkan dari serpong. Proses rekrutmen tenaga pendidik di MAN Insan Cendekia Jambi antara lain: perencanaan dengan menganalisis kebutuhan guru, pelaksanaan rekrutmen, seleksi, wawancara dan magang. Pelaksanaan rekrutmen tenaga pendidik di MAN Insan Cendekia Jambi sudah berjalan dengan baik sesuai dengan yang diharapkan tanpa ada interpensi dari pihak manapun meskipun masih ada beberapa hambatan.

3. Madrasah yang bermutu dipengaruhi oleh berbagai unsur, tapi unsur yang paling menentukan dalam proses belajar mengajar adalah guru, untuk mendapatkan guru yang profesional dan berkualitas sangat tergantung pada pelaksanaan rekrutmen tenaga pendidik. Proses rekrutmen tenaga pendidik pada MAN Insan Cendekia Jambi dengan bekerja sama dengan MAN Insan Cendikia Serpong sudah dilaksanakan dengan baik dan selektif sehingga diperoleh tenaga pedidik yang ikhlas, berkualitas, dan loyalitas, yang tentunya sangat besar memberikan kontribusi terhadap mutu madrasah ini.

\section{Kepustakaan}


Bukhori, Imam, Shohih Bukhori, Juz I, (Bairut; Daar Al Kutub, 2008)

Danim, Sudarwan, Visi Baru Manajemen Sekolah dari Birokrasi ke Lembaga Akademik, (Jakarta: Bumi Aksara, 2006)

Echol, Jhon M. dan Hassan Shadily, Kamus Inggris Indonesia, (Jakarta:Gramedia Pustaka Utama, 2003)

Irwin, Fundamentals of Human Resource Management, (New York: McGraw-Hill, 2011),

Jacobsen, David A., Paul Eggen, Donald Kauchak, Metode-metode Pengajaran Meningkatkan Belajar Siswa TK-SMA, (Yogyakarta: Pustaka Pelajar, 2009)

Karwati, Euis, dan Donni Juni Priansa, Kinerja dan profesionalisme kepala sekolah Membangun Sekolah yang bermutu, (Bandung: Alfabeta, 2013)

Mukhtar, Metode praktis Penelitian Deskriptif Kualitatif, (Jakarta: Referensi (GP Press group, 2013),

Moleong, Lexy J. Metodologi penelitian Kualitatif Edisi Revisi, (Bandung: PT. Remaja Rosdakarya, 2005)

Mulyasa, E, Menjadi Kepala Sekolah Profesional (Bandung: Remaja Rosdakarya, 2007)

Mulyasana Dedi, Pendidikan Bermutu dan Berdaya Saing, (Bandung: PT. Remaja Rosdakarya, 2012)

Putra, Nusa dan Santi Lisnawati, Penelitian Kualitatif Pendidikan Agama Islam, (Jakarta: Remaja Rosdakarya, 2012)

Sallis, Edward, Total Quality Management in Education, (Jogjakarta: IRCiSoD, 2006)

Siagian, Sondang P., Manajemen Sumber Daya Manusia, (Jakarta: Bumi Aksara, 2009)

Sugiyono, Metode penelitian Kuantitatif Kualitatif, dan R\&D, (Bandung: Alfabeta, 2013)

Supiana, Sistem Pendidikan Madrasah Unggulan di Madrasah Aliah Negeri Insan Cendekia Tangerang, Madrasah Aliyah Negei I Bandung dan Madrasah Aliayah Negeri Darussalam Ciamis, (Badan Litbang Dan Diklat Depag RI, 2008)

Suwatno dan Doni Juni Priansa, Manajemen SDM dalam Organisasi Publik dan Bisnis (Bandung: Alfabeta, 2013),

Wukir, Manajemen Sumber Daya Manusia Dalam Organisasi Sekolah, (Yogyakarta: Multi Presindo, 2013) 